\title{
Pengaruh Konversi Antibiotik Intravena ke Rute Per-oral terhadap Outcome Ekonomi, Klinis dan Humanis pada Pasien Rawat Inap
}

\author{
Laksmi Maharani ${ }^{1}$, Esti D. Utami ${ }^{1}$, Ika Mustikaningtias ${ }^{1}$, \\ Masita W. Suryoputri ${ }^{1}$, Pugud Samodro ${ }^{2}$ \\ ${ }^{1}$ Jurusan Farmasi, Fakultas Ilmu-Ilmu Kesehatan, Universitas Jenderal Soedirman, \\ Banyumas, Indonesia, ${ }^{2}$ Jurusan Kedokteran Umum, Fakultas Kedokteran, \\ Universitas Jenderal Soedirman, Banyumas, Indonesia
}

\begin{abstract}
Abstrak
Konversi terapi intravena ke rute per-oral dengan memperhatikan perbaikan hemodinamik pasien dalam 48 jam dapat menghemat biaya pengobatan tanpa mengabaikan efektivitas terapi. Penelitian ini bertujuan untuk mengetahui pengaruh intervensi konversi antibiotik intravena ke rute per-oral terhadap outcome klinis berupa lama rawat inap dan konversi angka leukosit pasien; outcome humanis berupa kualitas hidup pasien (WHOQOL-BREF), dan outcome ekonomi berupa biaya antibiotik pasien. Penelitian ini menggunakan desain kuasi-eksperimental dengan kelompok intervensi dan kontrol, single blind, tanpa randomisasi. Subjek penelitian adalah pasien yang mendapatkan antibiotik seftriakson intravena yang dirawat inap di bangsal penyakit dalam RSUD Prof. Dr. Margono Soekarjo, Purwokerto selama bulan September sampai Oktober 2017. Pasien intervensi mendapatkan intervensi berupa konversi antibiotik lebih awal, yaitu 2 hari setelah diberikan antibiotik intravena. Dilakukan perbandingan lama rawat inap, penurunan angka leukosit, biaya antibiotik, dan kualitas hidup pasien antara kelompok kontrol dan intervensi menggunakan analisis statistik Mann-Whitney dan Independent t-test. Hasil penelitian ini menunjukkan bahwa dari 22 subjek yang terbagi dalam 6 pasien intervensi dan 16 pasien kontrol, terjadi penurunan rata-rata lama rawat inap pasien intervensi dibanding kontrol 3,167:5 hari. Rata-rata biaya antibiotik pada kelompok intervensi lebih rendah dibanding kelompok kontrol yaitu Rp73.886,8 dan

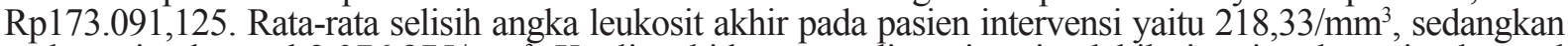
pada pasien kontrol $2.076 .875 / \mathrm{mm}^{3}$. Kualitas hidup yang dicapai pasien lebih tinggi pada pasien kontrol $(+6,6875)$ dibandingkan pasien intervensi $(-1,33)$ walaupun perbedaan tersebut tidak berbeda signifikan $(>0,05)$. Konversi lebih awal seftriakson intravena menjadi sefiksim oral mampu menurunkan lama rawat inap dan menurunkan biaya antibiotik yang dikeluarkan secara signifikan $(0,017$ dan 0,003$)$.
\end{abstract}

Kata kunci: Konversi antibiotik intravena ke oral, outcome ekonomi klinis dan humanis (ECHO), sefiksim, seftriakson

\section{Impact of Intravenous to Oral Antibiotic Switch Therapy towards Economic, Clinical and Humanistic Outcome in Inpatients}

\begin{abstract}
Antibiotic conversion from intravenous form to oral form (IV to oral switch) after 48 hours therapy in hemodynamically stable patients can save the cost of treatment without neglecting the effectiveness of therapy. This study aimed to determine the influence of early switch antibiotic from iv to oral on economic clinical humanistic outcome (length of stay in hospital and white blood cell conversion as clinical outcome; quality of life as humanistic outcome using WHOQOL-BREF, and antibiotic cost as economic outcome). This was a quasi-experimental research with control and intervention group, without blinding and randomization. Subjects were inpatients who received ceftriaxone at internal medicine wards of Prof. Dr. Margono Soekarjo hospital for 2 months period from September until October 2017. Intervention group received early antibiotic conversion after 2 days. Length of stay, white blood cell count, quality of life and antibiotic cost were compared between control and intervention groups using Mann-Whitney and Independent t-test. The result showed that from the total of 22 subjects who were divided into intervention group (6 subjects) and control group (16 subjects), there was a decrease in average length of stay of intervention group compared to control (3.167 days and 5 days, respectively). The average of antibiotic cost in intervention group was lower than control group (IDR 73,886.8 and IDR 173,091.125, respectively). The average of white blood cell count in intervention group was 218.33/ $\mathrm{mm}^{3}$ while in control group was $2,076,875 / \mathrm{mm}^{3}$. Quality of life of control group was higher $(+6,6875)$ compared to intervention group $(-1,33)$ but was not statistically significant. Early antibiotic switch from ceftriaxone to cefixime could reduce the length of stay and antibiotic cost significantly $(0.017$ and $0.003)$.
\end{abstract}

Keywords: Cefixime, ceftriaxone, economic clinical humanistic outcome, intravenous to oral switch therapy antibiotic

Korespondensi: Laksmi Maharani, M.Sc., Apt., Jurusan Farmasi, Fakultas Ilmu Kesehatan, Universitas Jenderal Soedirman, Banyumas, Jawa Tengah 53122, Indonesia, email: laksmimaharani22@yahoo.co.id Naskah diterima: 11 Juli 2018, Diterima untuk diterbitkan: 11 Juni 2019, Diterbitkan: 28 Juni 2019 


\section{Pendahuluan}

Resistensi antibiotik merupakan masalah yang semakin berkembang di dunia pengobatan penyakit infeksi akhir-akhir ini. ${ }^{1}$ Penggunaan antibiotik yang berlebihan dan tidak tepat menjadi faktor penyebab terjadinya resistensi, di samping tidak adanya penemuan antibiotik baru. ${ }^{1} \mathrm{Hal}$ ini juga menyebabkan peningkatan mortalitas dan biaya pengobatan pasien. ${ }^{2}$ Lama dan biaya rawat pasien akan mengalami peningkatan pada penggunaan antibiotik yang tidak sesuai. ${ }^{3}$ Konversi terapi dari intravena ke rute per-oral dapat menghemat biaya pengobatan tanpa mengabaikan efektivitas terapi, juga akan memberikan manfaat pada penghematan biaya pengobatan, peningkatan kenyamanan pasien, penurunan waktu rawat inap, pengurangan kemungkinan terjadi komplikasi dan penurunan risiko infeksi akibat injeksi intravena. ${ }^{4}$

Penggantian antibiotik dari intravena ke rute per-oral dapat dilakukan pada sekitar 38\%$67,6 \%$ pasien infeksi. ${ }^{5,6}$ Sebuah penelitian yang telah dilakukan sebelumnya menunjukkan bahwa pasien yang menggunakan antibiotik intravena mendapatkan manfaat terbesar jika dikonversi pada hari kedua atau ketiga terapi. ${ }^{7}$ Seftriakson merupakan salah satu antibiotik terbanyak yang diresepkan di rumah sakit di Indonesia. Penggunaannya mencapai $43 \%$ hingga $46 \%$ pada penelitian sebelumnya, ${ }^{8,9}$ dan di RSUD Prof. Dr. Margono Soekarjo, penggunaan seftriakson untuk pasien-pasien di bangsal penyakit dalam berkisar $70-80 \%$ sebagai terapi empiris. Antibiotik seftriakson seringkali dikonversi menjadi antibiotik sefiksim saat pasien pulang dari rumah sakit dan membutuhkan terapi antibiotik oral. Penelitian sebelumnya menunjukkan bahwa pasien yang diberikan konversi antibiotik intravena ke rute per-oral memiliki outcome yang sama dengan konversi antibiotik seftriakson menjadi sefiksim ${ }^{8}$. Tujuan penelitian ini adalah untuk mengetahui pengaruh intervensi konversi antibiotik intravena ke rute per-oral terhadap outcome klinis berupa lama rawat inap dan konversi angka leukosit pasien; outcome humanis yang berupa kualitas hidup pasien, dan outcome ekonomi yang berupa biaya antibiotik pasien.

\section{Metode}

Penelitian ini dilakukan dengan desain kuasi -eksperimental dengan kelompok intervensi dan kontrol. Tidak dilakukan blinding dalam penelitian ini, hal ini karena pasien intervensi mendapatkan antibiotik secara oral setelah 48 jam terapi, sedangkan pasien kontrol tetap mendapatkan antibiotik secara intravena setelah 48 jam terapi.

Subjek penelitian ini adalah pasien yang mendapatkan antibiotik seftriakson intravena selama dirawat inap di bangsal penyakit dalam di RSUD Prof. Dr. Margono Soekarjo, Purwokerto selama bulan September hingga Oktober tahun 2017. Pasien yang menjadi subjek penelitian harus memenuhi kriteria inklusi dan eksklusi untuk dapat menjadi subjek. Kriteria inklusi penelitian antara lain pasien yang menerima antibiotik seftriakson dengan diagnosis infeksi nonviral atau febris dengan suspect infeksi; tidak mendapatkan antibiotik dalam 1 minggu terakhir sebelum dirawat di RSUD Prof. Dr. Margono Soekarjo; pasien rawat inap di bangsal penyakit dalam baik pasien rujukan dari poliklinik maupun pasien gawat darurat, dan apabila mengalami transisi perawatan dari IGD, maksimal 24 jam telah dipindahkan ke bangsal penyakit dalam; telah memenuhi kriteria penggantian antibiotik intravena ke rute per-oral pada hari rawat kedua setelah pemberian antibiotik (denyut nadi $<100$ kali per menit, respiratory rate $<$ 24 kali per menit, tidak ada tanda shock/tidak menggunakan obat vasopressor, tekanan darah sistolik $>90 \mathrm{mmHg}$, dan suhu $<38,3^{\circ} \mathrm{C}$ ); dan bersedia menjadi responden penelitian dibuktikan dengan menandatangani informed consent serta dapat mengikuti seluruh tahapan 
penelitian ini (termasuk prosedur kembali kontrol ke rumah sakit pada saat antibiotik habis). Kriteria eksklusi yang diterapkan pada penelitian ini antara lain pasien yang mendapatkan kombinasi antibiotik, pasien dengan komplikasi infeksi lainnya (TB, HIV), pasien sepsis, pasien dengan gangguan multi organ, pasien immunocompromised, pasien yang mendapatkan terapi kortikosteroid, dan pasien dengan usia $\geq 65$ tahun.

Pemilihan subjek untuk masuk ke dalam kelompok intervensi dan kontrol dilakukan tanpa randomisasi, yaitu dengan berdasarkan kesediaan dokter penanggung jawab pasien untuk bekerjasama dalam penelitian dengan melakukan konversi antibiotik intravena ke rute per-oral lebih awal. Terapi seftriakson intravena dikonversi menjadi sefiksim oral sesuai dengan grup subjek. Pasien intervensi menerima konversi antibiotik intravena ke rute per-oral lebih awal, yaitu 2 hari setelah diberikan antibiotik seftriakson intravena. Pasien kontrol dilakukan konversi antibiotik intravena ke rute per-oral saat akan keluar rumah sakit.

Outcome yang dinilai pada pasien adalah lama rawat inap, penurunan angka leukosit, biaya antibiotik, dan kualitas hidup pasien. Lama rawat inap dihitung sejak pasien masuk ke bangsal penyakit dalam hingga saat keluar dari rumah sakit. Penurunan angka leukosit dihitung dengan membandingkan angka leukosit awal dan akhir pada masing-masing kelompok. Biaya antibiotik yang dihitung meliputi harga antibiotik setriakson intravena selama diberikan di rumah sakit, spuit $5 \mathrm{cc}$ untuk menginjeksikan antibiotik seftriakson ke dalam cairan pencampur, harga $\mathrm{NaCl} 0,9 \%$ piggyback 100 cc sebagai cairan pencampur dalam pemberian seftriakson, serta harga antibiotik sefiksim. Perspektif biaya dilakukan menggunakan perspektif rumah sakit. Biaya yang diukur sebagai hasil akhir adalah biaya penghematan antibiotik. Outcome ekonomi lain yang dihitung adalah nilai Average Cost
-Effectivenenss Ratio (ACER). Nilai ACER dihitung menggunakan perbandingan biaya pengobatan masing-masing pasien dengan outcome klinis yang dicapai pasien. Tidak dilakukan perhitungan nilai Incremental Cost Effective Ratio (ICER), hal ini disebabkan tujuan penelitian ini yaitu untuk menentukan penghematan biaya, sehingga biaya subjek yang diberikan intervensi pasti lebih rendah dibandingkan subjek yang menjadi kelompok kontrol. Kualitas hidup pasien diukur pada saat sebelum dan setelah dilakukan intervensi menggunakan kuesioner WHOQOL-BREF. Domain yang diukur adalah kesehatan fisik, psikologis, hubungan sosial, dan lingkungan. Kuesioner ini telah dilakukan uji validitas dan reliabilitas ulang setelah diterjemahkan menggunakan bahasa Indonesia. Hasil dari uji validitas dengan menggunakan korelasi Pearson Product Moment menunjukkan nilai r pada domain kesehatan fisik, hubungan sosial, dan hubungan sosial seluruhnya di atas nilai $r$ tabel untuk 22 sampel dengan tingkat signifikansi 5\%, yaitu 0,432 (r 0,468 hingga 0,980 ), sedangkan untuk domain lingkungan hanya 3 dari 5 pertanyaan yang valid (nilai r 0,504 hingga 0,786) sehingga analisis data untuk kuesioner WHOQOL-BREF hanya menggunakan tiga domain, yaitu kesehatan fisik, psikologis, dan hubungan sosial. Hasil uji reliabilitas menggunakan Cronbach alpha pada sebanyak 22 sampel memberikan hasil nilai 0,959, dengan kata lain, kuesioner ini dianggap reliabel untuk digunakan. Pengujian validitas, reliabilitas maupun analisis data yang dilakukan pada kuesioner WHOQOLBREF total hanya menggunakan 24 item dari seluruh item, karena pertanyaan 1 dan 2 tidak diperhitungkan dalam skor total sesuai dengan pedoman penilaian kuesioner oleh World Health Organization (WHO).

Hasil nilai skor rata-rata masing-masing parameter dilakukan uji normalitas dengan menggunakan uji statistik KolmogorovSmirnov. Parameter klinis berupa lama rawat 
inap memiliki data yang tidak terdistribusi normal sehingga diuji statistik menggunakan analisis statistik Mann-Whitney, sedangkan parameter yang datanya terdistribusi normal yaitu penurunan angka leukosit, biaya antibiotik, dan kualitas hidup pasien diuji menggunakan Independent t-test.

Penelitian ini telah mendapatkan izin dari pihak RS Prof. Dr. Margono Soekarjo Purwokerto. Selain itu, penelitian ini juga telah mendapatkan persetujuan etik berdasarkan keputusan ethical approval dari Medical and Health Research Ethics Committee (MHREC) Fakultas Kedokteran Universitas Gadjah Mada dengan nomor referensi KE/FK/0950/EC/ 2017.

\section{Hasil}

Karakteristik pasien

Pasien yang memenuhi kriteria inklusi yakni sebanyak 95 orang, akan tetapi, pada proses penelitian hanya 76 pasien yang masuk ke dalam kriteria eksklusi. Tiga alasan terbesar penyebab tingginya angka eksklusi pasien menjadi subjek adalah penolakan dari pasien (21\%), durasi penggunaan antibiotik yang tidak sesuai (18\%), serta pasien mendapatkan kombinasi antibiotik di tengah perjalanan penelitian (12\%). Pasien yang menjadi subjek penelitian berjumlah 22 orang (Tabel 1). Pada penelitian ini, diagnosis yang paling banyak ditemukan pada subjek penelitian adalah febris, infeksi saluran cerna, dan infeksi saluran kemih. Data diagnosis lainnya dapat dilihat pada Tabel 2.

Pengaruh konversi antibiotik intravena ke rute per-oral terhadap outcome ekonomis, klinis dan humanis

Prosedur konversi antibiotik intravena ke rute per-oral dilaksanakan dengan mengganti terapi antibiotik dari seftriakson intravena menjadi sefiksim oral setelah pasien dinilai stabil dalam 48 jam. Proses prosedur ini lebih cepat dibandingkan yang selama ini diterapkan di rumah sakit, yaitu penggantian baru dilakukan saat pasien hendak pulang dari rumah sakit. Outcome yang diamati pada penelitian ini yakni economic, clinical, and humanistic outcome (ECHO) yang dapat dilihat pada Tabel 3.

\section{Outcome ekonomi}

Hasil penelitian ini menunjukkan layanan konversi antibiotik intravena ke rute per-oral mampu menurunkan biaya antibiotik yang dikeluarkan. Biaya antibiotik yang dikeluarkan lebih rendah secara signifikan $(\mathrm{p}<0,05)$ antara kelompok yang diberi perlakuan dengan yang tidak diberi perlakuan. Hal ini dikarenakan penggunaan antibiotik seftriakson intravena di rumah sakit pada kelompok kontrol berkisar antara 3 hingga 11 hari, dan durasi penggunaan antibiotik sefiksim lanjutan hanya 6 hingga 10 hari. Pada kelompok intervensi, lama penggunaan antibiotik sefiksim oral setelah 2 hari seftriakson intravena bervariasi mulai 7 hingga 10 hari. Penurunan biaya pengobatan

Tabel 1 Karakteristik Subjek Penelitian

\begin{tabular}{lccc}
\hline \multicolumn{1}{c}{ Karakteristik } & $\begin{array}{c}\text { Intervensi }(\mathbf{n ,} \%) \\
(\mathbf{n = 6 )}\end{array}$ & $\begin{array}{c}\text { Kontrol (n, \%) } \\
(\mathbf{n}=\mathbf{1 6})\end{array}$ & $\begin{array}{c}\text { Total }(\mathbf{n}, \mathbf{\%}) \\
(\mathbf{n}=\mathbf{2 2})\end{array}$ \\
\hline $\begin{array}{l}\text { Jenis Kelamin } \\
\text { Laki-laki }\end{array}$ & $2(33)$ & $10(63)$ & $12(55)$ \\
Perempuan & $4(67)$ & $6(38)$ & $10(45)$ \\
Usia (tahun) & & & $4(18)$ \\
$18-30$ & $1(17)$ & $3(19)$ & $5(23)$ \\
$30-40$ & $3(50)$ & $2(13)$ & $11(50)$ \\
$40-55$ & $1(17)$ & $10(63)$ & $2(9)$ \\
$55-65$ & $1(17)$ & $1(6)$ & \\
\hline
\end{tabular}


Tabel 2 Diagnosis Subjek Penelitian

\begin{tabular}{lc}
\hline \multicolumn{1}{c}{ Diagnosis } & Jumlah (n, \%) \\
\hline Infeksi Saluran Cerna & $7(32)$ \\
Febris & $6(27)$ \\
Infeksi Saluran Kemih & $4(18)$ \\
Infeksi Saluran Nafas & $1(5)$ \\
Batu Empedu & $1(5)$ \\
Tifoid & $1(5)$ \\
Hematochezia & $1(5)$ \\
Sindrom Mielodisplasia & $1(5)$ \\
Total & $\mathbf{2 2 ~ ( 1 0 0 )}$ \\
\hline
\end{tabular}

terhitung sebesar 57\% jika dilakukan konversi antibiotik lebih awal. Data biaya pengobatan kemudian dihitung menggunakan analisis biaya efektif (cost-effectiveness analysis), dan dilihat berdasarkan outcome lama rawat inap, nilai ACER ditemukan lebih rendah pada kelompok intervensi, sedangkan nilai ACER yang didasarkan pada outcome penurunan angka leukosit memiliki hasil lebih rendah pada kelompok kontrol. Perbedaan ini dapat terjadi karena pada outcome klinis berupa length of stay (LOS) pasien tidak mendapat blinding, sehingga pasien intervensi cenderung lebih cepat keluar dari rumah sakit akibat tidak ada obat yang perlu diberikan secara intravena lagi. Pada outcome klinis berupa penurunan nilai leukosit, penelitian ini tidak membatasi diagnosis penyakit infeksi yang dianalisis, sehingga variabilitas nilai leukosit pasien sangat besar. Hal ini dapat memengaruhi nilai ACER yang dihasilkan, karena ketidaksetaraan jenis infeksi yang diderita kelompok kontrol dan intervensi menyebabkan penurunan leukosit pada kedua kelompok tidak sebanding. Karena manfaat ekonomi yang dihasilkan pada dasarnya merupakan penghematan biaya, nilai ACER tidak dijadikan landasan penarikan kesimpulan manfaat ekonomi. Outcome ekonomi yang dinilai dalam penelitian ini hanya penurunan biaya antibiotik. Keterbatasan penelitian ini adalah tidak dilakukannya analisis sensitifitas untuk mengetahui apakah outcome ekonomi ini dapat diterapkan terus-menerus kedepannya.

\section{Outcome klinik}

Penelitian ini membuktikan bahwa layanan konversi antibiotik seftriakson intravena ke sefiksim oral lebih awal mampu menurunkan

Tabel 3 Economic, Clinical, and Humanistic Outcome Pasien Intervensi Dibandingkan Kontrol

\begin{tabular}{|c|c|c|c|}
\hline \multirow{2}{*}{ Parameter } & \multicolumn{2}{|c|}{ Rata-Rata Selisih Nilai Pre dan Post dan Standar Deviasi } & \multirow{2}{*}{$\begin{array}{c}\text { Nilai } \\
\text { Signifikansi }\end{array}$} \\
\hline & Intervensi & Kontrol & \\
\hline \multicolumn{4}{|l|}{ Klinis } \\
\hline Lama rawat inap & $3,167 \pm 1,679$ hari & $5 \pm 2,066$ hari & $0,017^{\mathrm{a} *}$ \\
\hline Penurunan angka leukosit & $218,33 \pm 5.588,171 / \mathrm{mm}^{3}$ & $2.076,875 \pm 3.329,246 / \mathrm{mm}^{3}$ & $0,345^{\mathrm{b}}$ \\
\hline \multicolumn{4}{|l|}{ Ekonomi } \\
\hline Biaya antibiotik & Rp73.886,8 $\pm 189,46$ & Rp173.091,125 $\pm 70.193,72$ & $0,003^{\mathrm{b} *}$ \\
\hline \multicolumn{4}{|l|}{ Humanistik } \\
\hline Kualitas hidup & $-1 \pm 4,926$ & $+6 \pm 13,572$ & $0,232^{\mathrm{b}}$ \\
\hline
\end{tabular}


Tabel 4 Average Cost-Effectiveness Ratio Berdasarkan Outcome Klinik Perkelompok

\begin{tabular}{|c|c|c|}
\hline \multirow{2}{*}{ Outcome Klinis } & \multicolumn{2}{|c|}{ Average Cost-Effectiveness Ratio } \\
\hline & Intervensi $(n=6)$ & Kontrol $(n=16)$ \\
\hline Length of Stay & Rp 23.332,67/hari rawat inap & $\mathrm{Rp} 34.618,23 /$ hari rawat inap \\
\hline Penurunan Nilai Leukosit & $\mathrm{Rp} 338,4128 / \mathrm{mm}^{3}$ penurunan leukosit & $\mathrm{Rp} 83,3421 / \mathrm{mm}^{3}$ penurunan leukosit \\
\hline
\end{tabular}

lama rawat inap namun tidak bermakna secara statistik. Lama rawat inap rata-rata pasien intervensi adalah 3,167 hari, dengan lama rawat paling lama 5 hari dan paling cepat 2 hari, sedangkan lama rawat inap pasien kontrol rata-rata 5 hari, dengan lama rawat inap paling lama 12 hari dan paling cepat 3 hari. Outcome klinis lain yang diamati adalah penurunan angka leukosit. Rata-rata penurunan angka leukosit akhir pada pasien intervensi lebih rendah dibandingkan pasien kontrol, namun perbedaan ini tidak bermakna secara statistik. Pada kelompok intervensi, terdapat sebanyak 5 orang yang mengalami penurunan angka leukosit dan sebanyak 1 orang mengalami peningkatan angka leukosit. Di sisi lain, pada pasien kontrol, terdapat sebanyak 15 orang mengalami penurunan angka leukosit dan sebanyak 7 orang mengalami peningkatan angka leukosit. Jika dilakukan perbandingan, maka sebesar $17 \%$ pasien intervensi tidak tercapai keberhasilan terapi dilihat dari angka leukositnya, sedangkan pada pasien kontrol sebesar 44\% tidak tercapai keberhasilan terapi dilihat dari angka leukositnya. Pada pasien intervensi, peningkatan angka leukosit setelah selesai terapi dialami oleh pasien dengan diagnosis tifoid, sedangkan pada kelompok kontrol, peningkatan angka leukosit setelah terapi antibiotik selesai dialami oleh pasien yang didiagnosis kolik abdomen, gastroenteritis akut, kolitis, penyakit refluks gastro-esofageal, infeksi saluran kemih (ISK) dan batu empedu. Sebagian besar diagnosis pasien kelompok kontrol yang tidak mengalami perbaikan nilai leukosit adalah infeksi gastrointestinal.

\section{Outcome humanistik}

Kualitas hidup pasien diukur dengan cara membandingkan hasil pre-test dan post-test kuesioner WHOQOL-BREF yang telah diisi pasien. Pre-test dilakukan saat pasien masih mendapatkan injeksi seftriakson intravena (yakni sebelum 48 jam), sedangkan post-test dilakukan saat pasien dinyatakan boleh keluar rumah sakit (yakni hari terakhir dirawat). Hasil penelitian ini menunjukkan bahwa kualitas hidup yang dicapai lebih tinggi pada pasien yang tidak diberikan perlakuan, meskipun perbedaan tersebut tidak berbeda signifikan ( $>0,05)$. Pada aspek kualitas hidup pasien intervensi, penurunan kualitas hidup dialami oleh 3 orang, sedangkan peningkatan kualitas hidup dialami oleh 3 orang. Di sisi lain, pada pasien kelompok kontrol, penurunan kualitas hidup dialami oleh 6 orang, sedangkan 10 orang

Tabel 5 Kualitas Hidup Pasien Intervensi Dibandingkan Kontrol Berdasarkan Domain WHOQOLBREF

\begin{tabular}{lcccccc}
\hline \multirow{2}{*}{ Domain } & \multicolumn{3}{c}{ Intervensi (n=6) } & \multicolumn{3}{c}{ Kontrol (n=16) } \\
\cline { 2 - 7 } & Pre & Post & Selisih & Pre & Post & Selisih \\
\hline Kesehatan Fisik & 23,17 & 23,17 & 0 & 21,13 & 23,13 & 2 \\
Psikologis & 24,17 & 23,83 & $-0,34$ & 19,44 & 22,31 & 2,87 \\
Hubungan Sosial & 9,83 & 8,83 & -1 & 10,06 & 10,94 & 0,88 \\
Lingkungan & 30,83 & 30,83 & 0 & 28,5 & 29,44 & 0,94 \\
Total Skor QOL & $\mathbf{8 8}$ & $\mathbf{8 6 , 6 6}$ & $\mathbf{- 1 , 3 4}$ & $\mathbf{7 9 , 1 3}$ & $\mathbf{8 5 , 8 2}$ & $\mathbf{6 , 6 9}$ \\
\hline
\end{tabular}


mengalami peningkatan kualitas hidup. Hal ini menunjukkan bahwa sebesar $50 \%$ pasien intervensi dan $37,5 \%$ pasien kontrol merasa mengalami penurunan kualitas hidup. Pada kelompok intervensi, pasien yang mengalami penurunan kualitas hidup dengan perbedaan yang cukup besar dari kualitas hidup semula di semua aspek memiliki diagnosis sindrom mielodisplasia (MDS), yang memang pada perjalanan penyakitnya, gangguan yang muncul semakin bertambah dari hari ke hari. Pasien yang mengalami penurunan kualitas hidup pada kelompok kontrol memiliki diagnosis ISK dengan penyerta kolik abdomen dan endometriosis, febris, ISK dengan dispepsia, vertigo melena, batu empedu, dan nyeri akut.

\section{Pembahasan}

Antibiotik seftriakson dipilih sebagai antibiotik yang dilakukan konversi antibiotik intravena ke rute per-oral disebabkan tingginya angka penggunaan antibiotik tersebut. Pada dasarnya, antibiotik seftriakson merupakan antibiotik spektrum luas yang efektif digunakan sebagai terapi berbagai macam infeksi ringan hingga sedang, yakni terapi infeksi saluran nafas, saluran cerna, empedu, dan tifoid. ${ }^{10}$ Pasien yang diberikan konversi antibiotik harus memenuhi syarat sesuai pedoman pelayanan kefarmasian untuk terapi antibiotik oleh Kementerian Kesehatan Republik Indonesia tahun 2011 yaitu denyut nadi $<100$ kali per menit, respiratory rate $<24$ kali per menit, tidak ada tanda shock/tidak menggunakan obat vasopressor, tekanan darah sistolik $>90$ $\mathrm{mmHg}$, dan suhu $<38,3^{\circ} \mathrm{C}$. ${ }^{4}$ Sefiksim dipilih sebagai pengkonversi dari seftriakson karena merupakan antibiotik yang berasal dari golongan yang sama dan memiliki potensi yang setara meskipun memiliki senyawa yang berbeda. ${ }^{7}$ Bioavailabilitas dari sefiksim adalah $60-90 \%$ sehingga sefiksim akan lebih cepat memberikan efek terapi dan akan lebih banyak masuk ke dalam sirkulasi darah. ${ }^{11}$
Hasil penelitian ini sejalan dengan hasil penelitian Mertz et al. (2009) di rumah sakit di Swiss, dan Setiawan et al. (2017) di rumah sakit di Surabaya mengenai kemampuan layanan konversi antibiotik intravena ke rute per-oral dalam menurunkan biaya terapi antibiotik., Hasil penelitian ini menunjukkan adanya penurunan biaya pengobatan sebesar 57\%. Penelitian lain di Arab Saudi oleh Hammad et al. (2016) menunjukkan konversi antibiotik dari intravena ke rute per-oral pada berbagai jenis antibiotik, termasuk seftriakson pada pasien dengan diagnosis gastritis, bronkhitis, gagal ginjal kronik dan pasien hemodialysis, mampu menurunkan biaya pengobatan hingga $64,7 \%$ (dari total 1674 SAR pada pasien yang tidak dilakukan switch menjadi 591 SAR pada pasien yang dilakukan switch). ${ }^{12}$ Penerapan antibiotik yang sesuai akan menghasilkan outcome ekonomis 59\% lebih baik dibanding konversi terapi yang tidak sesuai. ${ }^{13}$ Hal ini membuktikan bahwa penerapan konversi antibiotik dari rute intravena ke oral bermanfaat dari sisi ekonomis, dan hasil tersebut konsisten pada berbagai tempat dan variasi antibiotik.

Hasil penelitian lain oleh Mertz et al. (2009) menunjukkan adanya pengaruh dari konversi antibiotik intravena ke rute per-oral terhadap penurunan lama rawat inap secara bermakna meskipun jenis infeksi yang diderita oleh pasien berbeda-beda. ${ }^{5}$ Konversi antibiotik intravena ke rute per-oral yang dilakukan dalam sebuah penelitian multisenter pada pasien-pasien yang memiliki infeksi kulit, jaringan lunak, infeksi tulang dan sendi, infeksi saluran nafas, infeksi saluran kemih, infeksi intra-abdominal serta beberapa jenis infeksi lainnya, terbukti dapat mengurangi waktu tinggal di RS dan risiko komplikasi terkait penggunaan antibiotik intravena. ${ }^{13}$ Penelitian ini menunjukkan hasil yang sejalan bahwa lama rawat inap pasien yang mendapatkan konversi terapi antibiotik intravena ke rute per-oral lebih awal lebih rendah secara signifikan dibandingkan yang tidak mendapatkan konversi lebih awal. 
Hasil outcome klinis perubahan angka leukosit setelah menerima konversi antibiotik intravena ke rute per-oral lebih awal di penelitian ini lebih rendah dibandingkan dengan yang tidak menerima intervensi. Penelitian oleh Park et al. (2014) menunjukkan bahwa tidak ada perbedaan outcome kesembuhan pada pasien yang menerima konversi antibiotik intravena ke rute per-oral jika dilihat dari penurunan angka leukosit. ${ }^{14}$ Pasien yang menerima penggantian antibiotik yang tidak tepat memiliki outcome klinis yang tidak berbeda bermakna dengan yang mendapatkan antibiotik konversi secara tepat, walaupun outcome lama rawat inap dan biaya pengobatan menunjukkan perbedaan yang bermakna. ${ }^{15}$ Pasien yang tidak memiliki outcome konversi angka leukosit lebih baik di penelitian ini adalah pasien dengan diagnosis tifoid. Pilihan terapi utama pada tifoid adalah siprofloksasin, ${ }^{16}$ meski penggunaan seftriakson fase akut juga menghasilkan outcome klinis yang baik. ${ }^{17}$ Dengan kata lain, ketidaktepatan pemilihan antibiotik ini memengaruhi hasil penelitian jika dilihat dari outcome ekonomi berupa perbaikan konversi angka leukosit.

Outcome humanis yang diamati pada penelitian ini adalah kualitas hidup pasien. Penelitian yang dilakukan oleh Nafteux et al. (2012) di Belgia menunjukkan bahwa kualitas hidup pasien dipengaruhi oleh lama pengobatan. Pasien yang lebih cepat keluar dari rumah sakit setelah masa perawatan memiliki angka kualitas hidup yang lebih baik dari sisi fungsional dan perbaikan gejala. ${ }^{18}$ Hal ini berbeda dengan hasil penelitian ini. Pasien yang mendapatkan layanan konversi antibiotik intravena ke rute per-oral lebih awal memiliki lama pengobatan yang lebih pendek di rumah sakit, tetapi memiliki ratarata kualitas hidup yang lebih rendah. Pasien yang cenderung tidak mengalami perbaikan kualitas hidup setelah menerima konversi antibiotik yaitu pasien dengan diagnosis ISK. Penyakit ISK memang berkaitan dengan penurunan kualitas hidup disebabkan gejala- gejala yang timbul seringkali mengganggu waktu berkegiatan dan istirahat sehingga menyebabkan stres mental bagi pasien. ${ }^{19,20}$ Hal lain yang dapat memengaruhi kualitas hidup pasien yaitu kepatuhan terhadap terapi. Pasien yang patuh akan mendapatkan efikasi yang maksimal dari pengobatan sehingga kualitas hidupnya lebih baik. ${ }^{19}$ Pasien yang dirawat inap memiliki kepatuhan yang baik hingga $96 \%,{ }^{21}$ sedangkan pasien rawat jalan yang memiliki kepatuhan yang baik terhadap pengobatan antibiotik hanya $75,6 \%{ }^{22}$ Hasil dari penelitian lain di Kanada menunjukkan bahwa pasien yang keluar dari rumah sakit menunjukkan ketidakpatuhan terhadap terapi dimulai saat 7 hari setelah keluar dari rumah sakit (28\%) dan 30 hari setelah keluar dari rumah sakit (24\%). Salah satu pengobatan yang termasuk dalam kategori ketidakpatuhan tersebut adalah antibiotik. ${ }^{23}$ Pasien yang mengalami perbaikan klinis dan hilangnya gejala-gejala penyakit cenderung lebih tidak patuh untuk melanjutkan pengobatannya. ${ }^{24}$ Kualitas hidup pasien yang lebih rendah pada kelompok yang mendapatkan konversi antibiotik dapat terjadi akibat periode rawat inap yang lebih pendek, sehingga pasien merasakan perbaikan klinis dan cenderung lebih tidak patuh menjalani pengobatan.

Terdapat beberapa keterbatasan pada penelitian ini, salah satunya hanya diteliti satu jenis antibiotik untuk dikonversi menjadi bentuk sediaan oral. Hal ini menyebabkan jumlah sampel penelitian menjadi terbatas. Perlu dilakukan penelitian lanjutan untuk mengetahui adanya kemungkinan mengenai diterapkannya konversi antibiotik lebih awal pada jenis antibiotik lain. Intervensi yang diterapkan juga tidak sebanding, yaitu pemberian antibiotik melalui rute oral dan intravena, sehingga tidak dilakukan blinding. Hal ini merupakan keterbatasan penelitian lainnya yang dapat menjadi salah satu faktor yang memengaruhi outcome penelitian dari sisi psikologis. Perlu penyempurnaan metode 
intervensi apabila akan dilakukan penelitian sejenis di tempat lain dengan menggunakan jenis antibiotik yang sama.

\section{Simpulan}

Konversi antibiotik intravena ke rute per-oral lebih awal dari seftriakson menjadi sefiksim mampu meningkatkan outcome ekonomi dan klinik pasien berdasarkan penurunan lama rawat inap dan penurunan biaya antibiotik yang dikeluarkan $(\mathrm{p}<0,05)$. Pada outcome klinis yang berupa penurunan angka leukosit akhir, konversi antibiotik intravena ke rute per-oral lebih awal tidak memiliki pengaruh yang lebih baik. Konversi antibiotik intravena ke rute per-oral tidak berpengaruh terhadap peningkatan kualitas hidup yang dicapai pasien $(p>0,05)$.

\section{Pendanaan}

Penelitian ini dilaksanakan menggunakan dana BLU Universitas Jenderal Soedirman tahun anggaran 2017.

\section{Konflik Kepentingan}

Seluruh penulis menyatakan tidak terdapat potensi konflik kepentingan dengan penelitian, kepenulisan (authorship), dan atau publikasi artikel ini.

\section{Daftar Pustaka}

1. Ventola CL. The antibiotic resistance crisis, part 1: Causes and threats. $\mathrm{P} \mathrm{T}$. 2015;40(4):277-83.

2. Founou RC, Founou LL, Essack SY. Clinical and economic impact of antibiotic resistance in developing countries: A systematic review and meta-analysis. PLoS One. 2017;12(12):e0189621. doi: 10.137 1/journal.pone.0189621

3. Sadikin ZD. Penggunaan obat yang rasional. J Indon Med Assoc. 2011;61(4): $145-8$.

4. Kementerian Kesehatan Republik Indonesia. Pedoman pelayanan kefarmasian untuk terapi antibiotik. Jakarta: Kementerian Kesehatan Republik Indonesia; 2011.

5. Mertz D, Koller M, Haller P, Lampert ML, Plagge H, Hug B, et al. Outcomes of early switching from intravenous to oral antibiotics on medical wards. $\mathrm{J}$ Antimicrob Chemother. 2009;64(1):18899. doi: 10.1093/jac/dkp131.

6. Beeyene BA, Kassie GM. Current practice and barriers to an early antimicrobial conversion from intravenous to oral among hospitalized patients at Jimma University specialized hospital: Prospective observational study. Interdiscip Perspect Infect Dis. 2019;2019:7847354. doi: 10.1 155/2019/7847354.

7. Cyriac JM, James E. Switch over from intravenous to oral therapy: A concise overview. J Pharmacol Pharmacother. 2014;5(2):83-7. doi: 10.4103/0976-500X. 130042

8. Luciana T, Andrajati R, Rianti A, Khan AH. Rational antimicrobial use in an Intensive Care Unit in Jakarta, Indonesia: A Hhospital-based, cross-sectional study. Trop J Pharm Res. 2015;14(4):707-14. doi: 10.4314/tjpr.v14i4.21

9. Setiawan E, Felix H, Setiadi AP. Analysis of the utilization and cost of antibiotics at an intensive care unit in Surabaya. Pharmaciana. 2017;7(2):213-230. doi: 10. 12928/pharmaciana.v7i2.6767

10. Corbett A, Dana J, Fuller M, Gallagher J, et al. Drug information handbook. Ohio: Lexi-comp; 2015.

11. Brunton LL, Chabner BA, Knollmann B. Goodman \& Gilman's the pharmacological basis of therapeutics, $12^{\text {th }}$ edition. New York: Mc Graw-Hill; 2011.

12. Hammad MA, Alakhali KM, Shaik Mohammad AS, Alqahtani RM, H. 
Alshhrany SH, Alhassan NM, et al. Prospective study on adherence and pharmacoeconomics of antibiotic switching from intravenous to oral route. J Pharm Res Clin Pract. 2015;5(4):7-13.

13. Buyle FM, Metz-Gercek S, Mechtler R, Kern WV, Robays H, Vogelaers D, et al. Prospective multicentre feasibility study of a quality of care indicator for intravenous to oral switch therapy with highly bioavailable antibiotics. J Antimicrob Chemother. 2012;67(8):2043-6. doi: 10.1 093/jac/dks 145

14. Park TY, Choi JS, Song TJ, Do JH, Choi $\mathrm{S}-\mathrm{H}, \mathrm{Oh} \mathrm{H-C}$. Early oral antibiotic switch compared with conventional intravenous antibiotic therapy for acute cholangitis with bacteremia. Dig Dis Sci. 2014;59 (11):2790-6. doi: 10.1007/s10620-014-3 233-0

15. Masyithah L, Armenia N, Almahdy. Hubungan ketepatan switch therapy terhadap kesembuhan luka, lama rawatan dan biaya pengobatan antibiotik pasien apendisitis. J Sains Farm Klin. 2016;2(2): 145-9. doi: 10.29208/jsfk.2016.2.2.69

16. Ryan ET, Andreas J. Treatment and prevention of enteric (typhoid and paratyphoid) fever, 2018 [Accessed on: 14 December 2018]. Available from: https:// www.uptodate.com/contents/treatmentand-prevention-of-enteric-typhoid-andparatyphoid-fever

17. Hammad OM, Hifnawy T, Omran D, Tantawi MAE, Girgis NI. Ceftriaxone versus chloramphenicol for treatment of acute typhoid fever. Life Sci J. 2011; 8(2):100-5.

18. Nafteux P, Durnez J, Moons J, Coosemans W, Decker G, Lerut T, et al. Assessing the relationships between health-related quality of life and postoperative length of hospital stay after oesophagectomy for cancer of the oesophagus and the gastrooesophageal junction. Eur J Cardiothorac Surg. 2013;44(3):525-33. doi: 10.1093/ej cts/ezt064.

19. Alidjanov JF, Abdufattaev UA, Makhsudov SA, Pilatz A, Akilov FA, Naber KG, et al. New self-reporting questionnaire to assess urinary tract infections and differential diagnosis: Acute cystitis symptom score. Urol Int. 2014;92(2):230-6. doi: 10.1159/ 000356177

20. Wagenlehner F, Wullt B, Ballarini S, Zingg D, Naber KG. Social and economic burden of recurrent urinary tract infections and quality of life: Apatient web-based study (GESPRIT). Expert Rev Pharmacoecon Outcomes Res. 2018;18(1):107-17. doi: 10.1080/14737167.2017.1359543

21. Tumiwa NNG, Yamlean PVY, Citraningtyas G. Pelayanan informasi obat terhadap kepatuhan minum obat pasien geriatri di Instalasi Rawat Inap RSUP Prof. Dr. R.D. Kandou Manado. Pharmacon. 2014;3(3):310-5.

22. Wibowo R, Soediby S. Kepatuhan berobat dengan antibiotik jangka pendek di Poliklinik Umum Departemen Ilmu Kesehatan Anak Rumah Sakit Dr. Cipto Mangunkusumo, Jakarta. Sari Pediatri. 2008;10(3):171-6. doi: 10.14238/sp10.3. 2008.171-6

23. Fallis BA, Dhalla IA, Klemensberg J, Bell CM. Primary medication non-adherence after discharge from a general internal medicine service. PLoS One. 2013;8(5): e61735. doi: 10.1371/journal.pone.00617 35

24. Edi IGMS. Faktor-faktor yang mempengaruhi kepatuhan pasien pada pengobatan: Telaah sistematik. Medicamento. 2015;1(1):1-8. 